\title{
Cultural models of linguistic standardization ${ }^{\dagger}$
}

\author{
Dirk Geeraerts* \\ Department of Linguistics, Catholic University of Leuven, Blijde-Inkomststraat 21, PO Box 03308, B-3000 Leuven, Belgium
}

\section{Article info \\ History: \\ Received February 9, 2015 \\ Accepted September 18, 2015 \\ Published February 12, 2016}

Key words:

cultural models

cognitive linguistics

psycholinguistics

\begin{abstract}
In line with well-known trends in cultural theory (see Burke et al., 2000), Cognitive Linguistics has stressed the idea that we think about social reality in terms of models - 'cultural models' or 'folk theories': from Holland \& Quinn (1987) over Lakoff (1996) and Palmer (1996) to Dirven et al. (2001a, 2001b), Cognitive linguists have demonstrated how the technical apparatus of Cognitive Linguistics can be used to analyze how our conception of social reality is shaped by underlying patterns of thought. But if language is a social and cultural reality, what are the models that shape our conception of language? Specifically, what are the models that shape our thinking about language as a social phenomenon? What are the paradigms that we use to think about language, not primarily in terms of linguistic structure (as in Reddy 1979), but in terms of linguistic variation: models about the way in which language varieties are distributed over a language community and about the way in which such distribution should be evaluated?

In this paper, I will argue that two basic models may be identified: a rationalist and a romantic one. I will chart the ways in which they interact, describe how they are transformed in the course of time, and explore how the models can be used in the analysis of actual linguistic variation.
\end{abstract}

\section{Cultural models and language variation}

There are two preliminary remarks that I should make in order to situate the present paper against a wider background. First, the analysis is a marginal offshoot of a more central interest in empirical methods for studying linguistic variation and change. The work that I have been doing over the last ten years or so with my research group has specifically focused on various aspects of lexical variation and change: diachronic semantics (Geeraerts, 1997), the relationship between semantic and lexical variation (Geeraerts et al., 1994), and lexical variation within pluricentric languages such as Dutch (Geeraerts et al., 1999). Within the latter line of research, we have been particularly concerned with the development of quantitative techniques for measuring lexical variation and processes of lexical standardization (see $\$ 4$ below).

There are two ways, then, in which the present more or less essayistic paper links up with the more rigorous descriptive and methodological work that is my basic field of interest. For one thing, an investigation into linguistic usage needs to be complemented by an investigation into the way in which the users of the language perceive the actual situation. The cultural models that I will be talking about define, in a sense, basic language attitudes - and an adequate interpretation of language variation should obviously take into account language attitudes along with language behavior.

At the same time, both perspectives (the behavioral and the attitudinal) have links with Cognitive Linguistics. Whereas the attitudinal approach draws inspiration from the Cognitive Linguistic analysis of cultural models and folk theories, the descriptive approach is a further development of the Cognitive Linguistic interest in lexical-semantic variation as represented by prototype theory. Underlying the publications mentioned above is a logical line of development from semasiological prototype theory (Geeraerts,

\footnotetext{
${ }^{\dagger}$ Originally published in René Dirven, Roslyn Frank and Martin Pütz (eds.), 2003, Cognitive Models in Language and Thought. Ideology, Metaphors and Meanings, Mouton de Gruyter, Berlin/New York, p. 25-68, CrossRef.

*Email address: dirk.geeraerts@arts.kuleuven.be.
} 
1997) to a model of lexical variation encompassing onomasiological variation (Geeraerts et al., 1994), which then further broadens to the investigation of 'external', sociolectal and dialectal factors of variation (Geeraerts et al., 1999).

As a second preliminary remark, is there a difference between a 'cultural model' and an ideology? It is a common idea in Cognitive Linguistics that the cultural models underlying reasoning and argumentation are to some extent idealized entities (see, for instance, the notion of ICM's or 'Idealized Cognitive Models' as introduced in Lakoff, 1987). Actually occurring phenomena and situations usually differ to a smaller or a greater extent from the models that act as cognitive reference points: the models themselves, then, are to some extent abstract, general, perhaps even simplistic, precisely because we use them to make sense of phenomena that are intrinsically more complicated.

With regard to social phenomena, this means that cultural models may turn out to be not just idealized entities, but also ideological ones. Cultural models may be ideologies in two different respects: either when their idealized character is forgotten (when the difference between the abstract model and the actual circumstances is neglected), or when they are used in a prescriptive and normative rather than a descriptive way (when they are used as models of how things should be rather than of how things are). In the latter case, an ideology is basically a guiding line for social action, a shared system of ideas for the interpretation of social reality, regardless of the researcher's evaluation of that perspective. In the former case, an ideology is always to some extent a cover-up, a semblance, a deliberate misrepresentation of the actual situation, and a description of such ideologies will of necessity have to be critical.

The distinction is of course well-known in ideology research, and there is an extensive linguistic literature probing the relationship between language and ideology. There are two basic (and to some extent overlapping) approaches here: on the one hand, all forms of critical discourse analysis, as represented by van Dijk (1998), Wodak \& Meyer (2001), or Blommaert \& Bulcaen (1997); and on the other, the 'ideologies of language' approach, as represented by Joseph \& Taylor (1990), Woolard et al. (1998), and Schiffman (1996). The former approach critically analyzes any text with regard to its position in the social power play-with regard to the way, that is, in which it reproduces or counteracts existing social relations. The latter approach concentrates on how beliefs about language variation and specific linguistic varieties manifest themselves explicitly (as in language policies) or implicitly (as in educational practices), and how they interact with group identity, economic development, social mobility, political organization.

In the following pages, I will not take a critical approach, but rather start from a neutral and descriptive conception of linguistic cultural models. Rather than critically analyzing specific practices and policies as ideological, I will try to explore the underlying structure and the historical development of the competing cultural models that lie at the basis of such practices and policies as well as their critical analysis.

\section{The rationalist and the romantic model}

In this section, I will present the two basic cultural models that I think need to be distinguished if we want to get a grip on the logic of standardization debates: the rationalist one and the romantic one. I will present them in mutual contrast, showing how they are to a large extent each other's counterpart, and how they are dialectically related. The present section will not however exhaust the comparison between both models. In the next section, the comparison will be further expanded, leading to the identification of two historical transformations of the basic models, in the form of a nationalist and a postmodern model.

\subsection{The rationalist model}

So what are the characteristics that are ideally (and perhaps ideologically) attributed to standard languages? The most conspicuous feature is probably the generality of standard languages. Standard languages, in contrast with dialects and other restricted languages, are general in three different ways.

They are geographically general, in the sense that they overarch the more restricted areas of application of dialects. Further, they are socially general because they constitute a common language that is not the 
property of a single social group but that is available to all. Finally, they are thematically universal in the sense that they are equipped to deal with any semantic domain or any linguistic function. More advanced domains of experience in particular (like science or high culture) fall outside the range of local dialects.

Because of their generality, standard languages have two additional features. First, they are supposed to be a neutral medium, with a mediating function, in an almost philosophical sense of 'mediation'. Standard languages, in fact, transcend social differences: they ensure that men and women from all walks of life and from all corners of the nation can communicate freely.

In that sense, they are a medium of participation and emancipation. Because of their neutrality and because of their functional generality, standard languages are a key to the world of learning and higher culture: functional domains par excellence for standard language use (or, reversing the perspective, functional domains that cannot be accessed on the basis of dialect knowledge alone). Perhaps even more importantly, standard languages are supposed to contribute to political participation. The possibility of free communication is a feature of a democratic political organization, in the sense of the ideal 'herrschaftsfreie Kommunikation' as described by Jürgen Habermas. If then linguistic standardization contributes to mutual understanding and free communication, it is a factor of political emancipation-just as it is a factor of social emancipation when it contributes to the spreading of culture and education. By contrast, if you believe in the beneficial effects of standardization, dialects are mere relics of an obscurantist social and political system that opposes democracy and emancipation.

In a context of postmodern ideological debunking, such a positive conception of standardization is definitely suspect, but it is crucial for my line of argumentation that at least in the context in which it originated (that of the $18^{\text {th }}$ century Enlightenment), there was a genuine positive appraisal of standardization. To illustrate, let us have a look at some excerpts from reports presented to the revolutionary Convention in France. Barère (1975) puts matters as follows.

(1) Citoyens, la langue d'un peuple libre doit être une et la même pour tous. (1975, p. 297)

[Citizens, the language of a free people has to be one and the same for all.]

(2) Les lumières portées à grands frais aux extrémités de la France s'éteignent en y arrivant, puisque les lois n'y sont pas entendues. (1975, p. 295)

[The lumieres, when they are brought with great difficulty to the remote corners of France, die out when they arrive there, because the laws are not understood.]

(3) Laisser les citoyens dans l'ignorance de la langue nationale, c'est trahir la patrie; c'est laisser le torrent des lumières empoisonné ou obstrué dans son cours; c'est méconnaître les bienfaits de l'imprimerie, car chaque imprimeur est un instituteur public de langue et de législation. (1975, p. 296-297)

[To maintain the citizens in their ignorance of the national language is to betray the country. It permits the torrent of the lumières to be poisoned or obstructed in its course. It means disavowing the blessings of the printing press, because all publishers are public teachers of the language and the legislation.]

(4) Citoyens, les tyrans coalisés on dit: l'ignorance fut toujours notre auxiliaire le plus puissant; maintenons l'ignorance; elle fait les fanatiques, elle multiplie les contre-révolutionnaires; faisons rétrograder les Français vers la barbarie: servons-nous des peuples mal instruits ou de ceux qui parlent un idiome différent de celui de l'instruction publique. (1975, p. 291)

[Citizens, the allied tyrants have said: ignorance has always been our most powerful helper. It creates fanatics, it breeds counter-revolutionaries. Let's make sure the French degrade into barbarity: let's take advantage of the badly educated peoples or of those that speak a language that is different from that of public education.]

(5) Les habitants des campagnes n'entendent que le bas-breton; c'est avec cet instrument barbare de leurs penseés superstitieuses que les prêtres et les intrigants les tiennent sous leur empire, dirigent leurs consciences et empêchent les citoyens de connaître les lois et d'aimer la République. Vos travaux leur sont inconnus, vos efforts pour leur affranchissement sont ignorés. (1975, p. 292-293) 
[The inhabitants of the countryside speak only the Breton dialect. It is with that instrument of their superstitious way of thinking that the priests and the plotters keep them under their thumb, control their minds, and prevent the citizens from knowing the laws of the Republic. Your works are unknown to them, your efforts to bring them liberty are ignored.]

The characteristics that we have attributed to standard languages (generality and communicative neutrality, emancipatory and participatory effects, opposition to obscurantism) can be easily identified in these fragments. Fragment (1) expresses the generality and uniformity of the standard language. Fragments (2) and (3) stress the emancipatory function of knowledge of the standard: citizens who only know their dialect will not understand the laws of the Republic (the assumption being, of course, that these have a liberating effect), nor will they, more generally speaking, be able to profit from the benefits brought by the printed press. Fragments (4) and (5) associate dialects more directly with counter-revolutionary obscurantism: it is suggested that priests and 'tyrants' deliberately maintain ignorance by preventing the common people from acquiring the standard language.

A similar pattern can be found in the following quotes from Grégoire (1975), who actually presents an entire educational project to the Convention to 'abolish the dialects and generalize the use of the French language'. (His notion of 'dialect' actually includes not just the dialects of French, but also the different languages spoken in the territory of France, like German in the Alsace region, Flemish in the northern area, or Breton in Brittany.)

(6) Mais au moins on peut uniformer le langage d'une grande nation, de manière que tous les citoyens qui la composent puissent sans obstacle se communiquer leurs pensées. Cette entreprise, qui ne fut pleinement exécutée chez aucun peuple, est digne du peuple français, qui centralise toutes les branches de l'organisation sociale et qui doit être jaloux de consacrer au plutôt, dans une République une et indivisible, l'usage unique et invariable de la langue et de la liberté. (1975, p. 302)

[But at least one can standardize the language of a great nation, to the extent that all its citizens can mutually communicate their thoughts unhindered. Such an enterprise, which no people has fully achieved as yet, is worthy of the French nation, which centralizes all aspects of the social organization and which must endeavour to endorse as soon as possible, in a Republic that is one and indivisible, the sole and invariable use of language and freedom.]

(7) 'Il y a dans notre langue, disait un royaliste, une hiérarchie de style, parce que les mots sont classés comme les sujets dans une monarchie.' Cet aveu est un trait de lumière pour quiconque réfléchit. En appliquant l'inégalité des styles à celle des conditions, on peut tirer des conséquences qui prouvent l'importance de mon projet dans une démocratie. (1975, p. 316)

['There is in our language, a certain royalist said, a hierarchy of styles, because the words are classified just like the citizens in a monarchy'. This confession constitutes a ray of insight for any thinking person. If we apply the inegality of the styles to the inegality of the conditions under which people live, we may come to conclusions that prove the importance of my project (oflinguistic standardization through an educational language policy) in a democracy.]

(8) Tous les membres du souverain sont admissibles à toutes les places; il est à désirer que tous puissent successivement les remplir, et retourner à leurs professions agricoles ou mécaniques. Cet état de choses nous présente l'alternative suivante: si ces places sont occupées par des hommes incapables de s'énoncer, d'écrire dans la langue nationale, les droits des citoyens seront-ils bien garantis par des actes dont la rédaction présentera l'impropriété des termes, l'imprécision des idées, en un mot tous les symptômes de l'ignorance? Si au contraire cette ignorance exclut des places, bientôt renaîtra cette aristocratie qui jadis employait le patois pour montrer son affabilité protectrice à ceux qu'on appelait insolemment les petites gens. [...] Ainsi l'ignorance de la langue compromettrait le bonheur social ou détruirait l'égalité. (1975, p. 303)

[All members of the sovereign people are eligible for all positions. It is desirable that all may successively fill these positions, and afterwards return to their agricultural or industrial professions. 
This state of affairs yields the following alternative. If the positions are taken up by men incapable of expressing themselves or of writing in the national language, will the rights of the citizens be safeguarded by laws that are characterized by improper choice of words, by imprecise ideas, in short by all symptoms of ignorance? If on the contrary this ignorance prevents people from taking up office, then soon enough we will witness the rebirth of that aristocracy that once used the dialects to demonstrate its affability with regard to those that it insolently named 'the small people'. [...] Thus, ignorance of the language either compromises social happiness or destroys egality.]

Fragment (6) points to the communicative generality of the standard language: having a unitary language not only symbolizes the unity of the nation, but it also ensures that the citizens can freely communicate their thoughts. Fragment (7) symbolically links the absence of standardization to the pre-revolutionary situation: the existence of hierarchically ordered varieties within the language mirrors the hierarchical organization of society. Fragment (8) aptly describes the politically emancipatory function of standardization. The egalitarian ideal implies that any citizen can take part in the government of the nation; in fact, the ideal would be that all citizens successively fulfill political functions and then return to their professional environment. However, in order to be able to fulfill these functions, a thorough knowledge of the common language is necessary. People should not be prevented from taking up office by their ignorance of the language. Hence, an educational effort to ensure standardization is necessary: Grégoire is an ardent defender of the 'Ecole publique' as a standardizing force.

In $\$ 3$, I will describe the transformations that the rationalist, Enlightenment ideal of standardization goes through in the course of the last two centuries. Even in its transformed shape, however, the positive evaluation of standardization refers to one or another of the features mentioned here: a neutrally mediating communicative function, and an emancipatory and participatory effect, both of these supported by an educational system geared towards the spreading of the standard language.

\subsection{The romantic model}

The romantic conception of standardization may be easily defined in contrast with the two dominating features of the rationalist model. First, as against the emancipatory and participatory goals of the enlightened view, a romantic view will tend to point out that standard languages are themselves instruments of oppression and exclusion. At this point, of course, the analysis of standardization takes the form of an ideological criticism: it will argue that the enlightened ideals are not often realized, and that, in fact, processes of standardization typically achieve the reverse of what they pretend to aim at. Although the term is not often used, this type of critical discourse boils down to a demonstration that linguistic standardization exemplifies what Horkheimer \& Adorno (1947) called the 'Dialektik der Aufklärung' - the (negative) dialectic of Enlightenment. Horkheimer and Adorno argue that rationalist positions have a tendency to lead to their own dialectical counterpart (in the sense, for instance, in which a growing technical mastery of man over nature may lead to the destruction of the natural world).

Now, if we look back at the three types of generality that standard languages are supposed to characterize, it is easy to see that the actual realization of the ideal may tend to contradict the ideal-which is then a case in point of the 'Dialektik der Aufklärung'.

First, standard languages are supposed to be geographically neutral, but in actual practice, processes of standardization often have their starting-point in a specific region that is economically, culturally, and/or politically dominant. For people in the other, outer provinces, then, the standard language is not an impartial medium, but it rather affirms the dominance of the leading province. Standard French, for instance, is not just an unbiased language coming out of the blue; it is the language of the upper and the middle classes of Paris and the Ile-de-France, and it is associated with the role that the central province has played since the medieval era.

Second, standard languages are supposed to be functionally general, but in actual practice, they are typically used in cultural, educational, scientific, administrative, and political contexts-at least in those circumstances in which a language community is not entirely standardized. Non-standard varieties may 
then naturally acquire additional, contrastive overtones. For one thing, if the standard language is the language of public life, the non-standard varieties will be appreciated as the language associated with intimacy, familiarity, the personal rather than the public sphere. For another, if the standard language functions in typically intellectual contexts (education and science), non-standard varieties will be invested with emotional values. For speakers of a dialect, the dialect is often the language of the emotions, of spontaneity, of naturalness, in contrast with the official and educational language. Ironically, the functional generality of standard languages engenders a functional specialization, separating the public sphere from the personal, and the emotional sphere from the intellectual.

Third, standard languages are supposed to be socially neutral, but in actual practice, they are typically the language of an elite. The link between an economical, cultural, or political elite and the standard language is in fact an inevitable side-effect of the functional generality of standard languages. If standard languages are typically used in cultural, educational, scientific, administrative, and political contexts, then those speakers of the language that act in these contexts will more easily learn the standard language or adopt it as their first language than speakers who remain foreign to these functions. The outsiders may then perceive the greater linguistic proficiency of the elite as a factor contributing to social exclusion. In Grégoire's view, knowledge of the standard language contributes to social mobility, but conversely, the real social distribution of standard language functions may turn the standard language into an instrument of discrimination.

We can see, in other words, how the alleged generality of standard languages actually takes the form of a series of specializations. The process of standardization takes its starting-point in the language of specific regions, specific groups of speakers, specific domains and functions, and this largely inevitable fact may subvert the very ideal that standardization was supposed to serve. When that happens, the original ideal may be critically unmasked as an ideological pretence.

Needless to say, this dialectical reversal may also affect the educational system. If the standard language is recognized as an instrument of oppression, discrimination, social exclusion, the educational system will likewise be rejected as contributing to such processes of social exclusion. Rather than seeing the school as an institution that spreads knowledge of the common language (and knowledge in general), creating possibilities for social mobility, it will then be pointed out that the educational system, relying on perhaps more than contributing to the knowledge of the language, favors those language users whose background makes them more familiar with the standard language, and thus reproduces rather than neutralizes social inequality.

But why call this critical reversal of the appreciation of the standard language a 'romantic' model? Why not simply call it a 'realistic' or a 'critical' or an 'anti-ideological' one? The reason is that this critical stance is often (though not necessarily always) accompanied by a second feature, that may be contrasted with the second characteristic of the rationalist model. That is to say, we have just seen how a critical approach questions the emancipatory, participatory conception of the Enlightenment model. But what about the second feature? What about the communicative aspects of the rationalist model?

We get a truly 'romantic' model of language variation when the critical attitude towards official standards is coupled with a view of language as expression rather than communication. According to the Enlightenment perspective, languages are means of communication, and a standard language is a superior communicative tool because it is functionally general and socially neutral.

According to a romantic perspective, languages are primarily expressive rather than communicative. They express an identity, and they do so because they embody a particular conception of the world, a world view or 'Weltanschauung' in the sense of Herder. The link between this well-known romantic conception of the relationship between language and thought and the standardization debate will be clear. If languages or language varieties embody a specific identity, then a preference for one language or language variety rather than another implies that the specific identity of a specific group of people is neglected or denied. Not recognizing the language is not recognizing the language users. If some language varieties are relegated to second rate status through the existence of a standard variety, then the speakers 
of those language varieties are denied a fundamental right: the right to express themselves in their own language - the only language, in fact, that could do justice to their individual identity, according to the romantic conception of the relationship between language and identity.

A correlate of this position is the positive evaluation of variety. Whereas the rationalist approach cherished linguistic uniformity as the symbolic expression of a free and open community in which all citizens have equal rights to speech, the romantic approach values diversity as a recognition of a fundamental respect for different identities.

In short, a fully romantic view of language variation and linguistic standardization opposes the Enlightenment view of language as communication with a view of language as the expression of an individual identity. It opposes the emancipatory and participatory rationalist ideal with a critical view of standardization as a tool of discrimination and exclusion, and it opposes the positive appreciation of education as an instrument for the dissemination of linguistic knowledge with a fundamental distrust of schools as part of a system reproducing social inequality.

In order to illustrate this model, I will not (as I did in the case of the rationalist model) use an historical example, but I would like to have a brief look at the current debate about linguistic genocide and the international position of English. In that interlinguistic form of variation, English replaces the standard language of intralinguistic variation, and minority languages threatened with disappearance replace the non-standard varieties. All the objections that a romantic approach would level against a dominating standard variety, could then be applied against the international domination of English. Consider, as an example, the following excerpts from an abstract of Skutnabb-Kangas (2000) (The abstract, by the author herself, may be found on the author's homepage).

(9) Indigenous peoples and minorities are the main bearers of linguistic and cultural diversity in the world-over $80 \%$ of the world's languages exist in one country only and the median language has no more than 5,000 speakers. Some of the direct main agents of linguistic (and cultural) genocide today are parts of what we call the consciousness industry: formal educational systems and the mass media. [...] The book shows that the education of most minorities and indigenous peoples in the world is organized in ways which both counteract sound scientific principles and lead to the disappearance of linguistic and cultural diversity. [...] Schools are every day committing linguistic genocide. [...] They also do it by forcibly moving children from one group (indigenous or minority) to another group (the dominant group) through linguistic and cultural forced assimilation in schools. [...] This inevitably includes a consideration of power relations. The book shows how the formal educational systems participate in maintaining and reproducing unequal power relations, here especially between linguistic minorities and others, but also more generally, and how the ways of doing this have changed and are constantly changing, and how control and domination are resisted and alternatives are constantly created and negotiated, managed and controlled, and recreated. The deficiency-based models that are used in most minority education invalidate the linguistic and cultural capital of minority children and their parents and communities. They make the resources of dominated groups seem handicaps or deficiencies, instead of valued and validated non-material resources, or they render them invisible and therefore not possible to convert into material resources and positions of structural power. This happens just as much in global international relations and the Mcdonaldization of the world as it happens in ESL classrooms.

Regardless of whether Skutnabb-Kangas is right or not (see Joseph forthcoming for a critical reaction), the components of the romantic approach are conspicuously present in her statement. First, the disappearance of languages and the disappearance of cultures are equated. The very notion of 'linguistic genocide' in fact invokes the extermination of an entire people (or at least culture) together with its language. As opposed to this process of forced assimilation and disappearance, different cultures have to be accepted as fundamentally equal, and diversity should be treasured as an end in itself. Second, the international dissemination of English does not lead to emancipation and participation, but rather serves purposes of 
international oppression, notably by multinational companies. And third, the text has explicit misgivings about the role schools play in this linguistic and cultural power play.

\subsection{The rationalist and the romantic model and the origins of language}

In the previous pages, I have not only sketched the rationalist and the romantic model of standardization, but I have also indicated that they exhibit a specific and narrow relationship. Not only is one the counterpart of the other, but there is a dialectical relationship between the two, in the sense that actual processes of standardization seem to be caught in a negative 'dialectic of Enlightenment' in the course of which the positive rationalist ideals tend to be subverted, thus giving way to a romantic, critical appreciation of the standardization process. This dialectical relationship, which is summarized in Table 1 , does not however exhaust the links that exist between the two basic conceptions.

\begin{tabular}{|c|c|c|}
\hline & THE RATIONALIST MODEL & THE ROMANTIC MODEL \\
\hline $\begin{array}{l}\text { linguistic-philosophical } \\
\text { basis: }\end{array}$ & $\begin{array}{l}\text { language as a medium of } \\
\text { communication }\end{array}$ & $\begin{array}{l}\text { language as a medium of } \\
\text { expression }\end{array}$ \\
\hline $\begin{array}{l}\text { conception of } \\
\text { standardization: }\end{array}$ & $\begin{array}{l}\text { a democratic ideal: standard } \\
\text { language as a neutral medium } \\
\text { of social participation }\end{array}$ & $\begin{array}{l}\text { anti-ideological criticism: } \\
\text { standard language as a medium } \\
\text { of social exclusion }\end{array}$ \\
\hline $\begin{array}{l}\text { conception of language } \\
\text { variation: }\end{array}$ & $\begin{array}{l}\text { language variation as an } \\
\text { impediment to emancipation }\end{array}$ & $\begin{array}{l}\text { language variation as expressing } \\
\text { different identities }\end{array}$ \\
\hline
\end{tabular}

Table 1: The rationalist and the romantic models of standardization

In this section, I will have a brief look at the theoretical linguistic background of the basic models: is there a specific conception of language that goes hand in hand with either of the perspectives? I will argue that $18^{\text {th }}$ century theories about the origins of language complement the picture painted so far. It was suggested above that the romantic and the rationalist approach differ in their theoretical conception of language: the former starts from an expressive conception of language and the latter takes its starting-point in a communicative conception. The distinction between both perspectives can get more relief if we have a brief look at some of the theories on the origins of language that were formulated in the $18^{\text {th }}$ centuryin the period, that is, in which we situate the intellectual sources of the rationalist and the romantic conception of language variation. The expressive conception of the origins of language may be illustrated on the basis of Herder's views, while Condillac may serve as an illustration of the communicative view.

Herder's conception of language as the expression of an inner view of the world shapes the way in which he describes the birth of language: language arises when man expresses his understanding of the world. In the following passage, Herder explains how man, in giving names to the animals (in this case, a sheep) identifies and expresses a specific feature (in this case, the sheep's bleating).

(10) Weiss, sanft, wollicht—seine besonnen sich übende Seele sucht ein Merkmal,—das Schaaf blöcket! sie hat Merkmal gefunden. Der innere Sinn würket. Dies Blöcken, das ihr am stärksten Eindruck macht, das sich von allen andern Eigenschaften des Beschauens und Betastens losriss, hervorsprang, am tiefsten eindrang, bleibt ihr. Das Schaaf kommt wieder. Weiss, sanft, wollicht—sie sieht, tastet, besinnet sich, sucht Merkmal—es blöckt, und nun erkennet sies wieder! 'Ha! du bist das Blöckende!' fühlt sie innerlich, sie hat es Menschlich erkannt, da sies deutlich, das ist, mit einem Merkmal, erkennet und nennet (1978, p. 33)

[White, soft, woolly-its cautiously exercizing soul looks for a characteristic feature. The sheep bleats! It has found a feature. The inner sense is working. This bleating, which impresses it to the utmost, which detaches itself from all other visual or tactile features, which springs forth, which makes an impression, stays with it. The sheep comes back. White, soft, woolly-the soul sees, feels, reflects-the sheep bleats, and now it recognizes it! 'Ha! You are the bleating one', it feels within 
itself, it has recognized it in human fashion, because it has recognized and named the sheep clearly, that is, by means of a characteristic feature.]

Herder's story may be contrasted with Condillac's view about the origins of language. Whereas Herder looks for the origins of language in a cognitive, epistemological urge to identify things (and more specifically, to identify them in a specific way that reflects man's understanding of the things in question), Condillac points to a communicative situation. In his story about two children, he describes how a cry for help by one is recognized by the other, and is gradually conventionalized as a specific sign.

(11) Celui qui souffroit parce qu'il étoit privé d'un objet que ses passions lui rendoient nécessaire, ne s'en tenoit pas à pousser des cris: il faisoit des efforts pout l'obtenir, il agitoit sa tête, ses bras, et toutes les parties de son corps. L'autre, ému à ce spectacle, fixoit les yeux sur le même objet; et [...] il souffroit de voir souffrir ce misérable. Dès ce moment il se sent intéressé à le soulager, et il obéit à cette impression, autant qu'il est en son pouvoir. Ainsi, par le seul instinct, ces hommes se demandoient et se prêtoient de secours [...]. Cependant les mêmes circonstances ne purent se répéter souvent, qu'ils n'accoutumassent enfin à attacher aux cris des passions et aux différentes actions du corps, des perceptions qui y étoient exprimées d'une manière si sensibles (1973, p. 194-195).

[A person who suffered from being deprived of an object that his passions made necessary for him, did not restrict himself to shouting: he made an effort to obtain it, shook his head and arms and body parts. The other person, moved by this spectacle, fixed his gaze on the same object, and suffered from seeing the miserable other person suffer. From this moment on, he grows interested in coming to his relief, and he obeys this sentiment to the best of his powers. In this way, by instinct alone, men mutually ask and give help. [...] But such events could not repeat themselves often before people got used to attaching to the passionate cries and bodily actions the views that they expressed so tangibly.]

The difference between Herder and Condillac correlates with a difference in their view of the relationship between language and culture. Unlike Condillac, Herder does not think it possible to explain the origins of human language from instinctive emotional cries. Understanding needs to be present before human, conscious language can arise. In Condillac's account understanding or "réflection" takes shape gradually, through the use of signs in a communicative situation. For Herder, the birth of language presupposes the existence of a human culture, a culture that is being expressed in the language. From Condillac's point of view, human culture develops from instinctive beginnings through the use of signs and the development of language. (Compare Sapir, 1907 for a more elaborated view.)

If it is indeed correct that the intellectual origins of our cultural models of linguistic standardization have to be sought in the $18^{\text {th }}$ century, quotations (10) and (11) suggest that there was a link with the linguistic theorizing of that period. This recognition opens the way towards the broader historical study of the relationship between theories in linguistics and the philosophy of language on the one hand, and language policies on the other. To what extent have theories about the origin, nature, structure of language influenced the way in which people (and governments) have thought about matters of language variation and linguistic standardization? The existing literature offers many points of departure but mostly concentrates on standardization processes and language policies within a single language or nation. One interesting way to use the cultural models identified above, could be to see whether they can be used as the basis for a more synthetic view of these historical links between linguistic theory and standardization.

\section{The historical transformation of the models}

The present section will have a look at various distinctive moments in the development of the competing models, in particular charting the transformations that they go through in the $19^{\text {th }}$ and the $20^{\text {th }}$ centuries. First, I will argue that the nationalist model of standardization that rose to prominence in the $19^{\text {th }}$ century constitutes a specific blend of the rationalist and the romantic model. Further, I will have a look at the way in which our contemporary postmodern awareness influences the competition between the rationalist 
and the romantic model. It is an interesting question, by the way, whether the models ever occur in their purest form. Even in the examples from the French revolutionary period, a link with patriotic nationalism is present. If this is indeed the case, the models presented in the previous section are to be seen as analytic reference points, as 'idealized cognitive models' in the sense of Cognitive Linguistics.

\subsection{The $19^{\text {th }}$ century and the nationalist model}

Both the rationalist and the romantic model have a problem with the level at which they should be situated. If the rationalist model is carried to its extreme, it implies the necessity of a universal, international language. If the driving force behind standardization is maximizing mutual communication, then a universal language that transcends all existing language variation is to be recommended: the neutralization of interlinguistic variation complements the neutralization of intralinguistic standardization. And of course, the ideal of a universal, ideal language (Esperanto, Volapük and the like) is precisely the historical realization of this consequent interpretation of the rationalist approach.

In actual practice, however, Esperantist movements and the like remained marginal. The real level at which standardization processes took place, lay at a lower level-that of the nation. Starting from the Enlightenment model, there is a simple logic to this (which can, in fact, be identified in the quotations from Barère and Grégoire that we discussed): if standardization aims at democratic, political participation, then obviously the nation, as the ideal form of political organization, becomes the locus of standardization processes and the educational efforts supporting them. In itself, then, a link between nationalism and the rationalist view of standardization cannot come as a surprise. Linguistic standardization is primarily standardization within a nation, because it is within the nation that the processes of political decision making take place that linguistic standardization is supposed to contribute to.A terminological clarification may be useful at this point. 'Nationalism' is the political ideology in which a state, as a political organization, derives its political legitimacy from its people, rather than from tradition, divine right, or the like. A state that lives up to this requirement is a nation. Nationalism, in other words, claims that any state should be a nation. The nationalist relationship between the people and the state may be conceived of in two different ways: according to a distinction that is customary in the literature on nationalism, we may make a distinction between civic nationalism and identity nationalism. On the one hand, civic nationalism is the conception of nationalism in which the nation derives its legitimacy from the active participation of its citizens, through a system of political representation. This is the liberal, rationalist conception of nationalism. On the other hand, identity nationalism is the conception of nationalism in which the nation derives its political legitimacy from the cultural identity of the people. This is the romantic conception of nationalism.

'Nationalism' also refers to the claim and the efforts of a particular group to become a nation. Existing states are not necessarily nations according to the nationalist view: either because they do not achieve democratic legitimacy (the liberal point of view), or because they do not recognize the cultural identity of certain groups (the romantic point of view). Historically speaking, then, 'nationalist movements' may be either movements trying to establish a liberal democracy, or movements claiming independence for a specific group or region. (In contemporary usage, though, the focus tends to lie more on the latter type.)

The link between nationalism and language that we described above clearly involves the liberal, rationalist version of nationalism: if the nation derives its legitimacy from the active participation of its citizens, then maximizing mutual communication through standardization is an instrument of participation. But if we turn to identity nationalism, nationalism has a similar, and maybe even stronger link with a romantic conception of language. Whereas the rationalist perspective contains a tendency towards universality, the romantic perspective has a tendency towards individuality. If carried to its extreme, the romantic conception of language variation implies that each person may have his or her own language. Just like the rationalist perspective tends to maximize communicability, the romantic perspective tends to maximize individual variation. Again, in actual practice, this is an extreme position that can hardly be realized as such. Except perhaps in the romantic admiration for the 'individual voice of the poet' and the like, 
the romantic conception deals with the language of groups rather than with the language of individuals. The identity that is expressed by the language is the identity of a community, and the community is a nation when it acquires political autonomy. Hence the well-known romantic link between nationalism and language: see, among many others, Deprez \& Vos (1998). On the one hand, language correlates with identity according to the romantic model, and on the other, nations may derive their legitimacy from the cultural identity of the people (which is not to say that all nationalism is linguistic nationalism: as is well known, the sense of identity may come from many other sources, like religion or ethnicity).

From two different angles, then, nationalism links up with language, and this recognition may be linked to the distinction between two basic types of nationalism that is often made in political theory. On the one hand, civic nationalism is the conception of nationalism in which the nation derives its legitimacy from the active participation of its citizens, through a system of political representation. In such a liberal, rationalist conception, the common language is the medium of participation. On the other hand, identity nationalism is the conception of nationalism in which the nation derives its political legitimacy from the cultural identity of the people, and language is one of the factors establishing such identity.

The actual alliance between both forms of reasoning may be briefly illustrated by the following quotes from Verlooy (1979). A Dutch-speaking lawyer in Brussels, which was then under Austrian rule, Verlooy argues against the growing use of French in public life and in favor of the use of the native Dutch tongue. In 1789, Verlooy played a role in the 'Brabantse Omwenteling', an (ineffective) insurrection against the Austrians. His pamphlet of 1788 may be read as the intellectual basis of his nationalist stance of the next year. But what is the role attributed to language in Verlooy's nationalism?

(12) Het is zonder twyffel een goed voor eenigelyk wel ter tael en ter spraek te zyn, en zyne redens vaerdig en onbelemmert te voeren. Doch hier toe is een' zekere frankheyd noodig. Maer, gelyk by ons gezien en geplogen is, wanneer zullen wy frank zyn in die vremde tael? (1979, p. 58)

[Without any doubt, it is good for any person to be able to speak fluently, and to engage in conversation freely. But to achieve this a certain candour is necessary. However, as can be observed in our case, when will we obtain such candour in this foreign language?]

(13) Door ons frans schynen wy van die middelbare geleertheyd en borgerlyke wysheyd af geheel het gemeyn, onze bestgemoedde en weetgirige borgers, ambachtslieden, akkermans, en onze vrouwen: die ' $t$ frans teenemael niet, of ten minsten zoo verre niet en weten, dat-ze ' $t$ met vermaek of zonder moyelykheid konnen lezen: die daer door als als gedoemt schynen tot een' gezogte onwetendheyd. (1979, p. 49)

[By speaking French, we separate from this common knowledge and this civic wisdom all the common people, our well-humoured and inquisitive townsmen, craftsmen, farmers, and our women: who do not know French, or at least not well enough to read it easily and efficiently, and who therefore seem to be condemned to ignorance.]

(14) Voor het vaderlanderschap eener natie is zeer dienstig zoo veel eygen en bezonder te hebben als mogelyk is (...) en zelfs hoe meer een' zaek uytwendigs heeft, gelyk de tael, dragten, toneelen, godsdienst, zeker plechten; hoe meer zy de gemoederen van 't volk zal aentrekken. [...] Waerom werken wy dan om zoo bekwamen band van vaderlanderschap, de moederlyke tael, te bannen? (1979, p. 59-60) [For a feeling of national identity within a nation, it is useful to have as many common and specific features as possible, and these features will more readily attract the hearts of the people to the extent that they can be externally observed, like the language, the attire, the theater and the public entertainments, the religion. Why then do we endeavour to discard our mother tongue, which constitutes such a strong tie of patriotism?]

Quotation (12) emphasizes the individual and emancipatory perspective: it is important for people to be able to express themselves freely, and this can only be guaranteed in their mother tongue. In the same vein, quotation (13) stresses the importance of a common language for an open communication within a given society and for the dissemination of knowledge: the further use of French would engender an 
undesirable rupture between the middle classes and the lower classes. By contrast, quotation (14) stresses the importance of a common identity for nation-building. Both rationalist and romantic themes, in other words, may appear in the discourse of proponents of nationalist movements.

With the development of the national movements in the $19^{\text {th }}$ century, though, the nationalist emphasis tended to fall more and more on the romantic notion of national identity. Minorities aspiring towards independence naively assume or explicitly construct an identity, and nation states may blatantly enforce a common identity, linguistic or otherwise. These processes are well known from the nationalism literature (in the line of Hobsbawm, Anderson, Gellner, Smith). For our present linguistic purposes, the crucial point is to see that this romantic nationalism reveals the paradoxes of the romantic cultural model that we identified above. The transition from the romantic model as described earlier to the nationalist model constitutes so to speak a 'Dialektik der Romantik' that parallels the 'Dialektik der Aufklärung', i.e. an almost natural process through which the original romantic model becomes subverted and contradicts and least some of its own starting-points.

The paradox of the romantically inspired nationalist model, in fact, is this. On the one hand, it claims recognition of diversity, equal rights, political independence for one (linguistic) group with regard to other groups. On the other, it has to assume an internal homogeneity within that group, for the simple reason that within the romantic logic, it is the identity of the group that legitimatizes the claim for recognition. And so, the identity may have to be imposed or constructed, and dissident voices within the group may have to be stifled.

The romantic model, then, is no less prone to contradictory developments than the rationalist one. In the linguistic debate, the specific form of the romantically nationalist position is a concern for the purity of the language. Defending the common language against foreign influences (loan words, basically) is at the same time a defense of the cultural identity of the people. In the nationalist subversion of the initial romantic model identities are not only expressed, but they are also made permanent. Again, the link between purism and nationalism is well-known, and there is an extended literature on purism. What I would like to stress, in this respect, is less the phenomenon as such, but rather how it fits into the overall pattern that defines the paradoxical logic of the rationalist and the romantic model of language variation.

This paradoxical logic, to sum up, resides in the following points. First, although the basic models are opposites, they find a common ground in the notion of nationalism. Because the rationalist model cannot easily realize its extreme universalist claims, and because the romantic model cannot easily realize its radical individualist claims, both models meet on a middle ground where groups of people claim political identity and independence. Second, this coalescence of the models does not annihilate the tensions that exist between them: the history of the past two centuries brims with examples of conflicts between a more rationalist Staatsnationalismus ( civic nationalism at the level of the nation-state) and a more romantic Volksnationalismus (ethnic or cultural identity nationalism). Third, in addition to the tensions between the models, we have to take into account tensions within each model: the rationalist model is subject to the danger of a discriminatory 'Dialektik der Aufklärung', and the romantic assumption of internal homogeneity may likewise have oppressive side-effects.

\subsection{The $20^{\text {th }}$ century and the postmodern awareness}

Living as we do in the aftermath of the nationalist era, we should complete our overview of the historical transformations of the cultural models of language variation by charting what changes are brought to the debate by our post-nationalist environment. The current situation can best be characterized by two overlapping developments: globalisation and postmodernism.

Globalisation is economic and political (to the extent that the growing importance of international organisations diminishes the older importance of the nation state). But it is also linguistic: the international spread of English almost realizes the old rationalist's dream of a universal language.

The postmodern awareness, on the other hand, resides in two features. First, the so-called 'disappearance of the Great Narratives' signals a weakening of the older patterns of interpretation. There is 
a great deal of suspicion with regard to the rationalist model of a smooth, emancipatory progress as well as (and perhaps more dominantly so) with regard to the nationalist model. Postmodern thinking is the self-consciousness of the late $20^{\text {th }}$ century: progress is not automatic, and nationalism is dangerous.

This critical attitude entails a second feature: if the old models are no longer self-evident, a dehierarchicalization and informalization occurs. If, for instance, the original hierarchical ordering of high culture and low culture is rejected as part of the old models of interpretation, then popular culture may claim equal rights with regard to high culture.

These two features imply that postmodernism is to a large extent a renewed form of the original romantic attitude: it renews the critical, 'countercultural' attitude with regard to the official stories, and it revives the claims for diversity.

The interesting question from our point of view is whether these changes lead to a fundamental transformation of the cultural models that are used to discuss language variation. Basically, there is a growing emphasis on the international relationship between languages rather than the national relationship between language varieties. The initial models of standardization are essentially models of standard languages in comparison with dialects or other varieties of the same language. In the nationalist era, the debate sometimes involves national languages as opposed to minority languages, but it is only in our days that the debate concentrates on the international relationship between different languages, viz. the relationship between English as a world language in comparison with local, possibly endangered languages.

Now, to the extent that the position of global English is at stake, the old opposition between rationalist and romantic attitudes receives a new impetus. I have shown above how Skutnabb-Kangas's argumentation about the treatment of minority languages is largely situated within what I would call a 'romantic' frame. At the same time, it is not difficult to see what form the basic pattern of a rationalist reply with regard to the position taken by Skutnabb-Kangas would probably take.

First, against the identification of language and culture, the rationalist could point to cases where the same language is unproblematically shared by different cultures, or conversely, where the same culture unites people with different languages.

Second, against the allegation that the international dissemination of English is discriminatory, the rationalist might want to stress the actual emancipatory effects of a knowledge of English. If English is indeed the key to international communication (and if, indeed, acquiring English is possible for all), then it can only be welcomed that more and more people are able to participate in that kind of communication.

At the same time, though, the contemporary discussions seem to lead to the development of a model based on a functional differentiation between the varieties involved-an 'and/and'-model rather than an 'either/or'-model, so to speak. In the discussion about the international situation in particular, there is a growing recognition that multilingualism is a natural situation. Interestingly, the shift towards multilingualism as a (so to speak) dialectic synthesis of the opposite forces may be derived from the rationalist as well as from the romantic model. In the previous section, we saw that the shift towards nationalism fitted into the logic of both basic models, if account was taken of the 'problem of levels'. At this point, we can see in a similar way that a new focus on multilingualism fits in with both models.

On the one hand, a multilingual solution seems to presuppose some form of functional distribution: one language is used for a specific set of circumstances, and the other for another set of circumstances. Such a diglossic or polyglossic situational specialization is not incompatible with the original rationalist model. After all, the rationalist model is motivated by a desire to assure maximal democratic participation in what are sometimes called 'secondary domains' of social life: specific, public domains of experience, to begin with higher education and political life. For the 'primary domains', beginning with the more private aspects of life, the existence of less uniform, more local language varieties does not fundamentally contradict the ideological basis of the model.

On the other hand, the postmodern twist of the romantic model entails a new attitude towards the question of personal identity. It is often said, in fact, that one of the hallmarks of the postmodern mentality is the fragmentation of identity. People no longer experience a single personal identity, but they 
exhibit a number of different, possibly shifting identities, of a professional, social, ethnic, cultural nature. Different languages may then, following the original 'expressive' logic of the romantic attitude, express this fragmentation (or perhaps rather multiplication) of identities.

Although multilingualism would thus appear to provide a possible synthesis of the initial models, the multilingual solution does not, however, completely remove the tensions. Just like the nationalist convergence of the models in the $19^{\text {th }}$ century engendered a tension between nation states and minorities, the multilingual convergence entails tensions about the exact functional and situational distribution of the language varieties. A simple case in point is the current reform of higher education in Europe. The imposition of a uniform Bachelor/Master system is intended, among other things, to stimulate student mobility, and this in turn increases the pressure to introduce English as a language of instruction at least at the Master level. But many, of course, are reluctant to accept such a functional restriction on the original national language.

Likewise, internal tensions within each model continue to crop up. For instance, those welcoming international English as an opportunity for all to participate equally in a global culture may easily be blind to the fact that access to English is not equal for all. And the champions of linguistic diversity may readily overlook the fact that the people they purport to defend often prefer the educational and professional opportunities provided by the non-native language (as appears to be the case, for instance, in most African countries that are ex-colonies of Britain).

All in all, then, we may sum up the present situation in a way that largely parallels the summary at the end of \$3.2. On the one hand, just like nationalism allowed for a coalescence between the rationalist and the romantic model, multilingualism may constitute a point of convergence for the post-nationalist manifestations of the models. On the other, just like nationalism did not abolish the basic tension between the models nor the internal tensions within the models, a multilingual model does not cancel out the tension between rationalistically seeing global English as a communicative and educational opportunity and romantically seeing it as a threat to diversity and local identity. At the same time, though, we should keep in mind that the multilingual model is only beginning to emerge, and that the positions in the current debate have not yet crystallized as much as they have in the older nationalism debate.

\subsection{Summarizing the models and their transformations}

We can now identify the pattern that emerges from the discussion in the previous pages. Referring to the philosophical and cultural climate of the $18^{\text {th }}$ century, we have distinguished between a rationalist and a romantic basic model of linguistic standardization. Starting from a communicative conception of language, the former stresses the emancipatory function of a common language as an instrument of political and educational participation. Starting, on the other hand, from an expressive conception of language, the romantic model stresses how the imposition of a standard language may discriminate specific cultural identities. There is, then, a tension between the models to the extent that they are each other's counterpart. That tension is enhanced by the 'Dialektik der Aufklärung', the mechanism, through which the implementation of the rationalist ideals may generate its own opposite.

In the successive transformations that the models undergo in the $19^{\text {th }}$ and the $20^{\text {th }}$ centuries, we have not only identified variants of the two models as such, but we have also indicated how the tension that exists between them reappears in different forms. Table 2 charts the various positions.

The $19^{\text {th }}$ century witnesses a partial convergence of the models round the concept of nationalism. Both basic models do, in fact, have a problem of levels: how general should the communicative community of the rationalist model be? And how specific can the identity get that is expressed according to the romantic model? Rather than going for (respectively) universalist or individualist extremes, the nationalist interpretation of the models focuses on an intermediate level. From the rationalist point of view, the nation is, by definition, the level at which democratic participation should be guaranteed. From the romantic point of view, the identity to be expressed is a common identity, the identity of the group that constitutes a nation. These two forms of nationalism are well known, of course: liberal nationalism (civic nationalism, 


\begin{tabular}{|c|c|c|c|}
\hline & $\begin{array}{l}18^{\mathrm{TH}} \text { CENTURY: } \\
\text { the basic models }\end{array}$ & $\begin{array}{l}19^{\mathrm{TH}} \text { CENTURY: } \\
\text { nationalism }\end{array}$ & $\begin{array}{l}\text { LATE } 20^{\mathrm{TH}} \text { CENTURY: } \\
\text { postmodernism }\end{array}$ \\
\hline $\begin{array}{l}\text { the rationalist } \\
\text { position: }\end{array}$ & $\begin{array}{l}\text { the common language as } \\
\text { an instrument of political } \\
\text { and educational partici- } \\
\text { pation }\end{array}$ & $\begin{array}{l}\text { the nation as the basis of a } \\
\text { liberal democracy }\end{array}$ & $\begin{array}{l}\text { global English as an } \\
\text { opportunity / multi- } \\
\text { lingualism as functional } \\
\text { specialization }\end{array}$ \\
\hline $\begin{array}{l}\text { the romantic } \\
\text { position: }\end{array}$ & $\begin{array}{l}\text { the standard language as a } \\
\text { discrimination of specific } \\
\text { identities }\end{array}$ & $\begin{array}{l}\text { the nation as a focus of } \\
\text { cultural or ethnic identity }\end{array}$ & $\begin{array}{l}\text { global English as a threat / } \\
\text { multilingualism as the } \\
\text { expression of fragmented, } \\
\text { postmodern identities }\end{array}$ \\
\hline $\begin{array}{l}\text { the tension } \\
\text { between both } \\
\text { positions: }\end{array}$ & $\begin{array}{l}\text { opposition between the } \\
\text { models, enhanced by the } \\
\text { 'Dialektik der Aufklärung' }\end{array}$ & $\begin{array}{l}\text { conflict between nation } \\
\text { states and ethnic / cultural } \\
\text { groups }\end{array}$ & $\begin{array}{l}\text { what is the exact shape of } \\
\text { the functional special- } \\
\text { ization? }\end{array}$ \\
\hline
\end{tabular}

Table 2: Cultural models of standardization and their historical transformations

Staatsnationalismus) sees the nation as the basis of a liberal democracy, and romantic nationalism (identity nationalism, Volksnationalismus) sees the nation as a focus of cultural or ethnic identity. The tensions between both are equally well-known: the liberal nation state need not coincide with a single cultural or ethnic group, and these groups may then claim a status as an independent nation. Needless to say, linguistic differences may play a crucial role in the definition of the groups involved. Note, in addition, that a federal political model constitutes a rather frequent compromise for the tension between claims of nation states and those of nationalist groups.

The late $20^{\text {th }}$ century is characterized by a process of political and economic globalisation that has its attitudinal counterpart in a postmodern view of the world, and that has its linguistic counterpart in the global spread of English. The debate accordingly shifts towards the position of English vis à vis local, possibly endangered languages. Although the process has not perhaps reached its culmination yet, the debate seems to find a new focus in the concept of multilingualism as a way of reconciling the different positions. In the same way in which the nationalist focus of the $19^{\text {th }}$ century followed logically from the initial models (through the problem of levels), the focus on multilingualism can be equally motivated on the basis of both models. For the rationalist model, multilingualism involves an acceptable functional specialization of different languages: if language is an instrument of communication, different communicative situations may require different languages. For the romantic model, multilingualism correlates with the fragmented identity of the postmodern individual: if people may so to speak have different identities, they may use different languages to express those identities. However, the shift towards multilingualism does not eliminate the tension: the exact functional specialization of the languages involved remains a cause for conflict.

\section{Applying the models}

The rationalist, romantic, nationalist, postmodern models that we have identified may basically be used in two different ways in linguistics. On the one hand, they may be used as the basis for an analysis of any discourse concerning problems of standardization. The previous pages have already given some examples of how the cultural models can be used in the analysis of the logic of standardization debates. In general, such an analysis identifies the components of a given discourse as expressing, amending, opposing aspects of the basic models. We could go one step further by identifying standard patterns of statements and replies that may be expected in this kind of discussion, but it is not my intention to do this systematically here. 
On the other hand, language attitudes based on one or the other of the models may influence the actual development of standardization processes. In the following sections, I will illustrate this second domain of application. I will do so by having a closer look at the work that I have been doing with my research team on the internal variation of contemporary Dutch. In $\$ 4.1$, I will summarize the main results. (This section could be skipped by readers less interested in the technicalities of the project.) In $\$ 4.2$, I will discuss the way in which the cultural models of standardization may be brought to bear on the findings of the project.

\subsection{Contemporary Dutch as a pluricentric language}

Dutch basically comes in two varieties: Dutch as used in The Netherlands, and Dutch as used in the Flanders region of Belgium (sometimes referred to as 'Flemish'). The situation of the standard language in both countries is somewhat different. In Flanders, the standardization process that started off (as in most European countries) in the Early Modern Period was slowed down as a result of Flanders' political separation from The Netherlands during the Eighty Years' War. Standard Dutch developed in The Netherlands in the course of the $17^{\text {th }}$ century, but as Flanders was politically separated from The Netherlands, remaining under foreign (Spanish or Austrian) rule, it did not link up with this process of standardization. Rather, French was used more and more as the language of government and high culture, a practice that received an important impulse after the birth of the Belgian state in 1830. Dutch then survived basically in the form of a variety of Flemish dialects.

However, as a result of a social and political struggle for the emancipation of Flanders and the Flemishspeaking part of the Belgian population, Dutch again gained ground as a standard language (the language of learning, government, and high culture) in Flanders. This process started somewhat hesitantly in the late $19^{\text {th }}$ century as a typically romantic movement, gained momentum during the first half of the $20^{\text {th }}$ century, and finally made a major leap after World War II and during the booming 1960s. Still, most linguists agree that the standardization process has not yet reached its final point, or at least, that the level of standardization has not reached the same height as in The Netherlands.

The latter observation is the starting-point for our research: can we quantify the relationship between Belgian Dutch and Netherlandic Dutch (and the internal stratification of both varieties)? Can we calculate how close or how distant both varieties of Dutch are with regard to each other? More specifically (given that our research team is primarily interested in lexical variation), how does one quantify lexical convergence or divergence between two language varieties? In Geeraerts et al. (1999), a measure of lexical overlap was developed, based on the notions onomasiological profile and uniformity.

The onomasiological profile of a concept in a particular source is the set of synonymous names for that concept in that particular source, differentiated by relative frequency. Table 3 contains the onomasiological profiles for overhemd 'shirt' in the Belgian and the Netherlandic 1990-database:

\begin{tabular}{lcc} 
& Belgian Dutch 1990 & Netherlandic Dutch 1990 \\
\hline hemd & $31 \%$ & $17 \%$ \\
overhemd & $69 \%$ & $46 \%$ \\
shirt & $0 \%$ & $37 \%$
\end{tabular}

Table 3: Onomasiological profiles for shirt

Uniformity is a measure for the correspondence between two onomasiological profiles. Our computation of uniformity has its starting-point in the idea that a common language norm triggers uniform linguistic behavior. In its most extreme form, lexical uniformity in the naming of a concept obtains when two language varieties have an identical name for that concept, or several names with identical frequencies in the two varieties. Much more frequent than these examples of 'ideal' uniformity, however, are such partial correspondences as illustrated in Table 3. Let us, for the sake of illustration, assume that the relative frequencies in Table 3 represent 100 actual naming instances in each of both profiles, rather than percentages. The partial overlap between the profiles in Table 3 is quantified by counting the naming instances 
for which there is a counterpart in the other profile. In the ideal scenario outlined above, each of the 100 naming events in each of both profiles has its counterpart in the other profile, yielding a maximal uniformity of 100\%. In Table 3, however, 14 instances of hemd in B90 have no counterpart in N90, 23 Belgian overhemden have no Netherlandic counterpart, and there are no Belgian counterparts for the 37 Netherlandic shirts. On the grand total of 200 naming events in the two profiles, only $200(14+23+37)=126$ instances have counterparts in the other profile, which yields a uniformity of $126 / 2=63 \%$. For the sake of quantitative convenience, it should be noticed that this percentage equates the sum of the smallest relative frequency for each alternative term, i.e. $17+46+0=63 \%$.

If more than one concept is investigated, a uniformity index $U$ is defined as the average of the uniformity indexes of the separate concepts, whereas uniformity index $U$ ' is defined as a weighted average, in which the relative frequency of each concept in the investigated samples is taken into account. In the present context, we will focus exclusively on the weighted uniformity $U$ ', in which high frequency concepts have a more outspoken impact on the overall uniformity.

The empirical foundation of the research project consisted of 40000 observations of language use. We collected the different names (and their frequencies) used to denote thirty concepts, fifteen from the field of clothing terminology, and fifteen from the field of football (i.e. soccer) terminology. The resulting database allows us, for instance, to calculate the proportion in Belgian and Netherlandic sources of the term buitenspel 'offside' and the loanword offside for the concept OFFSIDE; in the case of the concept JURK 'dress', we can determine whether the lexical choices involve a preference for either jurk, japon, or kleed. The core of the observed material consisted of magazine and newspaper material recorded in 1990.

This core was extended in two ways. In the first place, similar material was collected for 1950 an 1970 , which enabled us to carry out a 'real time'-investigation of lexical convergence or divergence processes. In addition, the stratification of language use was taken into account. Between standard and dialect, there are a number of 'strata' on which register differences may co-occur with an increasing geographical specialization. For an investigation of the relationship between Belgian and Netherlandic Dutch, these strata-viz. the regionally colored informal variants of the standard language-are extremely relevant: it can be expected that the linguistic differences between Belgium and The Netherlands will increase on this regiolectic level. This intermediate level between dialect and written standard language was represented by the clothing terms we collected from labels and price tags in shop windows in two Belgian (Leuven and Kortrijk) and two Netherlandic towns (Leiden and Maastricht). The intended audience of this form of communication is more restricted than the national or binational audience which is the target of the magazines from which the core material was selected. The fact that we are dealing with written language in a semi-formal situation, on the other hand, ensures that we steer clear of the purely dialectal pole of the stratificational continuum.

Given this database, what can we expect to find with regard to the relationship between the various language varieties? With respect to the status and the development of Belgian Dutch, two uncontroversial hypotheses can be found in the linguistic literature. First, there is an expectation of diachronic convergence between Belgian and Netherlandic Dutch. The standardization process in Flanders is characterized by an explicit normative orientation towards Netherlandic Dutch: the standardization of Belgian Dutch took the form of an adoption of the Dutch standard language that existed already in The Netherlands. In addition, the unfinished character of the standardization of Belgian Dutch is believed to manifest itself in a larger synchronic distance between local and national language in Belgium than in The Netherlands; even to the untrained observer, it is obvious that the differences between regional and supraregional registers are much larger in Belgium than in The Netherlands.

The diachronic and the synchronic hypothesis may now be made operational in terms of uniformity values as defined above. Diachronically, convergence and divergence can be quantified as increasing or decreasing uniformity. Synchronically, the larger distance between national and local language we expect in Belgian Dutch, will manifest itself in a smaller uniformity between magazine and shop window material in Belgian Dutch than in Netherlandic Dutch. 


$\begin{array}{ll}\text { B50 / N50: } & 69,84 \\ \text { B70 / N70: } & 74,59 \\ \text { B90 / N90: } & 81,70 \\ \text { B90 / B } 1 \text { 90: } & 45,90 \\ \text { N90 / N } \text { Nw }_{\text {sw }} 90 & 67,75\end{array}$

Table 4: U' values comparing Belgium and The Netherlands (1950-1970-1990) and comparing written data from magazines and newspapers with local shop window data (1990)

Table 4 contains the relevant results. B50 stands for 'Belgian data from 1950', N50 stands for 'data from The Netherlands from 1950'. $\mathrm{B}_{\mathrm{sw}} 90$ refers to the shop window materials in Belgium, in contrast with B90, which stands for the data taken from magazines and newspapers. The data in Table 4 unambiguously confirm the diachronic as well as the synchronic hypothesis. Diachronically, the increase in uniformity between Belgian and Netherlandic Dutch suggests an evident lexical convergence between both varieties:

$\begin{array}{lll}\mathrm{U}^{\prime}(\mathrm{B} 50, \mathrm{~N} 50) & <\mathrm{U}^{\prime}(\mathrm{B} 70, \mathrm{~N} 70) & <\mathrm{U}^{\prime}(\mathrm{B} 90, \mathrm{~N} 90) \\ 69.84 & <74.59 & <\end{array}$

Synchronically, the delayed or unfinished standardization of Belgian Dutch manifests itself in a distinctly lower uniformity between the Belgian magazine and shop window data than between the Netherlandic magazine and shop window material:

$$
\begin{array}{ll}
\mathrm{U}^{\prime}\left(\mathrm{B} 90, \mathrm{~B}_{\mathrm{sw}} 90\right) & <\mathrm{U}^{\prime}\left(\mathrm{N} 90, \mathrm{~N}_{\mathrm{sw}} 90\right) \\
45.90 & <67.75
\end{array}
$$

\subsection{Cultural models and the evolution of Belgian Dutch}

The overall situation of the different varieties of Dutch may be summarized as in Figure 1. The left-hand side of the figure represents Netherlandic Dutch, whereas the right-hand side represents Belgian Dutch ('Flemish'). The vertical dimension represents the internal stratification of both national varieties, distinguishing between the register of standard speech, the colloquial register, and the local dialects. Distances in the figure symbolize linguistic distances. In the upper register, both national varieties are close to each other, but the distances increase in the lower registers. Crucially, the colloquial Belgian Dutch (colloquial Flemish) is much further apart from the high register in Belgium than the distance that exists between colloquial speech and polite speech in The Netherlands. So how would Belgian Dutch evolve?

Basically, there are three possibilities. First, the present situation is merely a transitory one in a gradual process of convergence and standardization. We have seen that there is some evidence for such a converging development, at least in the upper stratum of the language, and it might be assumed that this evolution will continue in the lower strata. In that case, colloquial Flemish is likely to move upwards in the figure, perhaps until it reaches a position that is similar to that of Netherlandic Dutch. Second, the process of convergence might be reversed. Typical features of colloquial Flemish might be incorporated into the standard register used in Belgium, and this informalization of the standard language may in turn lead to a growing distance in the highest stratum between Netherlandic Dutch and Belgian Dutch. And third, the situation might simply be stable.

Now, what I would like to suggest is that the actual choice from among these three logical possibilities may be determined at least in part by the extent to which the three models of standardization are prevalent within the language community.

The first possibility (in which colloquial Flemish moves upwards in the direction of the upper stratum) would receive the strongest impetus from a rationalist attitude towards processes of standardization. A growing tendency to participate in those activities that are typically associated with standard language 


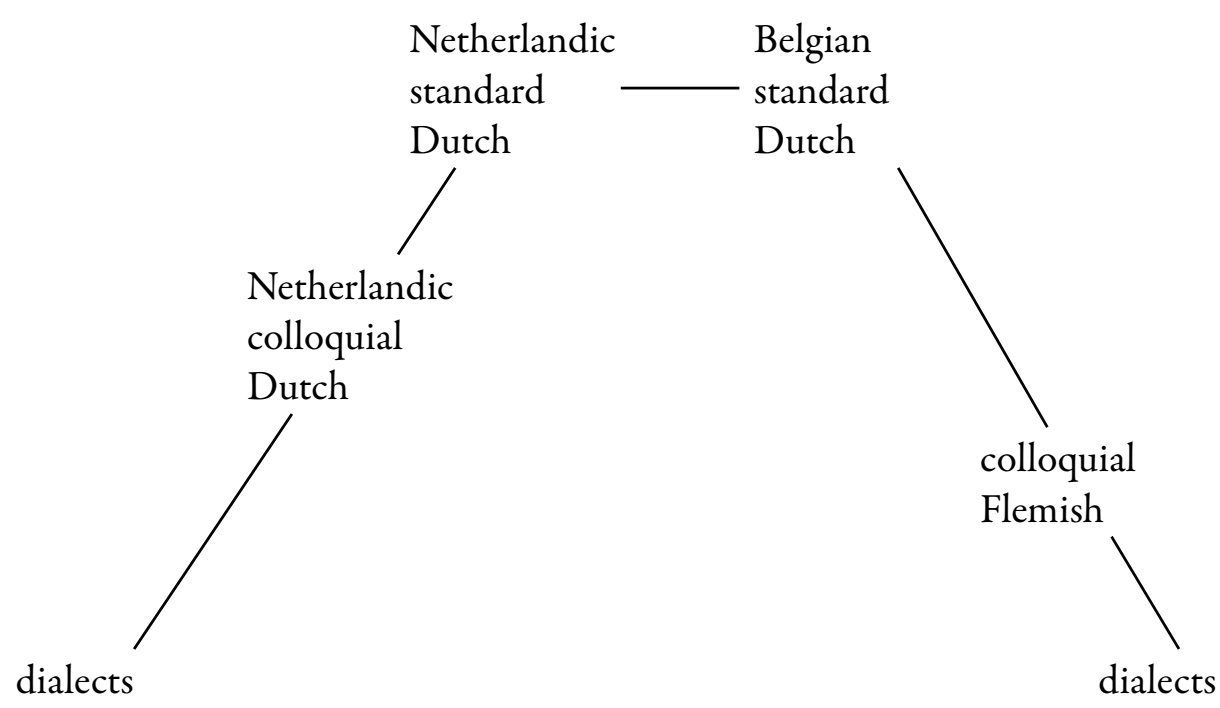

Figure 1: The stratificational structure of contemporary Dutch

use would go hand in hand with a further dissemination of the standard language in its present form. Whether this process would imply a further convergence of the upper register with Netherlandic Dutch is less clear: apart from the overall universalist aspect of the rationalist stance, i.e. the tendency to broaden the communicative scope of the language, the functional motivation for such a convergence would seem to be relatively weak.

We should note that a process of continuing convergence could also be triggered by a nationalist attitude, if the Flemish and the Dutch feel as one supra-national people, united by a common language across the borderline between Belgium and The Netherlands. However, although there exists a minor tradition of people advocating such an 'ethnic' union of Holland and Flanders, it plays no significant role in popular opinion. The feelings that exist between the Dutch and the Flemish are feelings of competition and gentle animosity rather than ethnic, language-based solidarity.

The second possibility (an increasing internal uniformity within Belgian Dutch, achieved through an informalization of the highest register) links up with the nationalist model. Flanders has achieved a political emancipation within Belgium, and this might be reflected in a growing linguistic independence-in the development, in other words, of an independent standard language norm that is increasingly different from the imported Netherlandic Dutch that was the initial reference point for the standardization process in Flanders. If the nationalist model prevails (and if it is oriented towards Flanders alone and not towards an 'ethnic' union of Holland and Flanders), the speakers of Flemish might develop a growing preference for the indigenous language forms that they encounter at the colloquial level rather than for the imported forms in the higher registers.

The third possibility (a status quo) has a romantic and postmodern ring to it, given that the romantic attitude in its purest form involves anti-establishment feelings. The romantic appreciation of standardization (if it is not lifted to the nationalist level) is basically a suspicious one: standardization is seen as a threat to diversity in general and to one's own local or individual identity in particular. Distancing himself from the official standard, the romantic has several options: he can plead for diversity (the acceptance of all varieties as equal) or he can try to impose his own language as the standard (the nationalist option), but he could also simply maintain the distance, accepting that there is a language for official occasions with which he does not identify, and a colloquial language in which he feels at home and that is sufficiently distant from the official language to be perceived as an expression of his own 'true' identity.

Are there any indications at all that Flanders might indeed have a mentality that favors such a stable form of diglossia? Its own popular self-image would certainly seem to support such a claim. Flanders perceives itself as being mildly anarchistic, in the sense that it is highly suspicious of official authorities, 
and in the sense that it does not take laws and regulations all too seriously. Tax evasion, for instance, is frequently described as a national sport. Also, historical reasons are often cited to explain this mentality. As mentioned above, Flanders has a history of foreign rule, and this is supposed to have engendered a mentality of critical distancing with regard to all forms of official authority. Postmodern tendencies towards informalization and dehierarchicalization would of course strengthen such an attitude. So, could it be that this mentality supports a romantically diglossic attitude in linguistic matters? The suggestion is certainly fascinating enough to warrant further empirically sound research about the mentality of the Flemings and their cultural history.

To be sure, I am not able to make any predictions about the probable course of events in Flanders. The evolution will certainly not only be determined by the attitudinal models mentioned here, and I do not have any attitudinal data yet that determine the strength of one or the other attitude. What I have tried to show, though, is that it makes sense to think about actual processes of standardization in terms of the cultural models identified in the first part of this paper. Cultural models of standardization are real not only to the extent that they shape public debate, but also to the extent that they lie at the basis of the language attitudes of the language users.

\section{Conclusions}

I have tried to do a number of things in this paper. First, I have argued that our thinking about questions of language variation and linguistic standardization can most often be reduced to two underlying, opposing cultural models: a rationalist one and a romantic one.

Second, I have suggested that the models originated in the $18^{\text {th }}$ century, and then went through a number of transformations in the course of the following two hundred years. Specifically, the $19^{\text {th }}$ century witnessed the development of a very influential nationalist model that combines elements of both basic models, and the late $20^{\text {th }}$ century witnessed a shift towards questions of globalization and the international position of English. At each of these stages, the models exhibit a certain tendency towards a coalescence, but at the same time, tensions remain - tensions between the models, and tensions within the models.

Finally, I have tried to demonstrate that the models in question cannot only be used in discourseanalytic fashion to scrutinize argumentations and discussions, but that they may also be seen as shaping the language attitudes of linguistic communities. If they have a real presence, they do not only show up in the way in which people talk about standardization, but also in the way in which they act.

Each of these points may be further developed. The identification of the models may be expanded towards a systematic map of standardization discussions, charting recurrent patterns of statements and replies. The historical sketch might be developed into a synthetic historical overview of standardization processes, standardization debates, and their relationship with linguistic theorizing. And the suggested link between models and language attitudes could lead to empirical attitudinal research. All of these possible developments, though, should contribute to a common goal: a better understanding of the underlying logic of standardization debates.

\section{Bibliography}

Barère, Bertrand (1975). Rapport du Comité de Salut Public sur les idiomes, in Certeau, M..de, Julia, D. \& Revel, J. (eds.), Une politique de la langue: la Révolution française et les Patois, p. 291-299, Éditions Gallimard, Paris. Original edition 1794.

Blommaert, J. \& Bulcaen, C. (eds.) (1997). Political Linguistics, John Benjamins, Amsterdam / Philadelphia, .

Burke, L., Crowley, T. \& Girvin, A. (eds.) (2000). The Routledge Language and Cultural Theory Reader, Routledge, London / New York.

Condillac, E. B.de (1973). Essai sur l'Origines des Sciences humaines, Porset, Ch. (ed.), Galilée, Auvers-sur-Oise. Original edition 1746.

Deprez, K. \& Vos, L. (eds.) (1998). Nationalism in Belgium: Shifting Identities, Macmillan, Basingstoke.

van Dijk, T.A. (1998). Ideology: A Multidisciplinary Approach, Sage, London, CrossRef.

Dirven, R., Hawkins, B. \& Sandikcioglu, E. (eds.) (2001a). Language and Ideology, I. Theoretical Cognitive Approaches, John Benjamins, Amsterdam / Philadelphia, CrossRef. 
Dirven, R., Frank, R. \& Ilie, C. (eds.) (2001b). Language and Ideology, II. Descriptive Cognitive Approaches, John Benjamins, Amsterdam / Philadelphia, CrossRef.

Geeraerts, Dirk (1997). Diachronic Prototype Semantics, Clarendon Press, Oxford.

Geeraerts, D., Grondelaers, S. \& Bakema, P. (1994). The Structure of Lexical Variation. Meaning, Naming and Context, Mouton de Gruyter, Berlin / New York, .

Geeraerts, D., Grondelaers, S. \& Speelman, D. (1999). Convergentie en Divergentie in de Nederlandse Woordenschat. Een Onderzoek naar Kleding - en Voetbaltermen, Meertens Instituut, Amsterdam.

Grégoire, H.-B. (1975). Rapport sur la nécessité et les moyens d'anéantir les patois et d'universaliser l'usage de la langue française, in Certeau, M.de, Julia, D. \& Revel, J. (eds.), Une politique de la langue: la Révolution française et les Patois, p. 300-317, Éditions Gallimard, Paris. Original edition 1794.

Herder, J. G. (1978). Abhandlung über den Ursprung der Sprache, Wolfgang Pross (editor), Hanser, München. Original edition 1772.

Holland, D. \& Quinn, N. (eds.) (1987). Cultural Models in Language and Thought, Cambridge University Press, Cambridge, CrossRef.

Horkheimer, M. \& Adorno, Th. W. (1947). Dialektik der Aufklärung, Querido, Amsterdam.

Joseph, J. \& Taylor, T. (eds.) (1990). Ideologies of Language, Routledge, London.

Lakoff, G. (1987). Women, Fire, and Dangerous Things. What Categories Reveal about the Mind, University of Chicago Press, Chicago, IL.

Lakoff, G. (1996). Moral Politics. What Conservatives Know and Liberals Don't, University of Chicago Press, Chicago, IL.

Palmer, G. (1996). Towards a Theory of Cultural Linguistics, University of Texas Press, Austin.

Reddy, M. (1979). The conduit metaphor - a case of frame conflict in our language about language, in Ortony, A. (ed.), Metaphor and Thought, Cambridge University Press, Cambridge, p. 284-384, .

Sapir, E. (1907). Herder's Ursprung der Sprache, in “Modern Philology”, 5, p. 109-142, CrossRef. Reprinted in "Historiographia Linguistica”, 11, p. 355-388 [1984], CrossRef.

Schiffman, H. (1996). Linguistic Culture and Language Policy, Routledge, London.

Skutnabb-Kangas, T. (2000). Linguistic Genocide in Education - or Worldwide Diversity and Human Rights?, Lawrence Erlbaum, Mahwah, NJ.

Wodak, R. \& Meyer, M. (eds.) (2001). Methods of Critical Discourse Analysis, Sage, London, CrossRef.

Woolard, K., Schieffelin, B. \& Kroskrity, P. (1998). Language Ideologies: Practice and Theory, Oxford University Press, Oxford. Verlooy, J. B. C. (1979). Verhandeling op d'Onacht der Moederlyke Tael in de Nederlanden. Smeyers, Jozef and Van den Broeck, Jan (eds.), Den Haag: Martinus Nijhoff. Original edition 1788. 